\title{
Histopathological changes in some organs of Japanese quail after different levels of jojoba meal
}

\author{
Abd El-Hakim ,N.F. ${ }^{1}$, Abou-Khashaba, H.A. ${ }^{2}$ and El-Sayed S. Atia ${ }^{2}$ \\ 1. Anim. Prod. Depart., Faculty of Agric., Al-Azhar Univ. \\ 2. Poult. Nutrit. Res. Depart., Animal Prod. Res. Instit., Agri. Res. Center, Giza, Egypt
}

\begin{abstract}
:
Aim of the work-The present study was conducted to investigate the effect of different jojoba meal as a replace of soybean protein and to detect the histopathological changes in some organs of Japanese quail (one week old) for 5 weeks.

Material and methods-The present study included two experiments, the first aimed to investigate the incorporation of treated jojoba meal seed (bentonite + autoclaving + fungus) in Japanese quail diets as replacer to soybean meal protein and to detect the histopathological changes in some organs of the Japanese quail. The treated jojoba meal was incorporated in the experimental diets to replace 0 (control); $4\left(\mathrm{~T}_{1}\right) ; 8\left(\mathrm{~T}_{2}\right)$ and $12 \%\left(\mathrm{~T}_{3}\right)$ of soybean meal protein. The second experiment, dietary treatment included the control diet (The same control of experiment I) and groups $2\left(\mathrm{UT}_{1}\right), 3\left(\mathrm{UT}_{2}\right), 4\left(\mathrm{UT}_{3}\right), 5\left(\mathrm{UT}_{4}\right)$, which were supplied with untreated jojoba meal at 0.0, 0.2, 0.4, 0.6 and $0.8 \%$ levels, respectively

Results- Observations of the present study showed that liver of $\mathrm{T}_{2}$ group revealed ruptured endothelial lining of the central vein, and $\mathrm{T}_{3}$ group showed elongated walls of the bile ducts. Ileum of $\mathrm{T}_{2}$ group showed highly thickened muscle layer and ileum of $\mathrm{T}_{3}$ group showed distorted tissue. Kidney of $\mathrm{T}_{2}$ group showed congested inters tubular spaces and $\mathrm{T}_{3}$ group showed normal convoluted tubules with congested and dilated blood vessels. Testis of $T_{2} \& T_{3}$ groups showed hypocellularity of cells of the spermatognic layers with absence of mature sperms. Ovary of $\mathrm{T}_{3}$ group showed somewhat normal mature ovum with reduced internal content.
\end{abstract}

Results of experiment II showed that the liver tissue was normal.Ileum of birds of $\mathrm{UT}_{3}$ and $\mathrm{UT}_{4}$ groups showed somewhat normal appearance. Kidney of $\mathrm{UT}_{3}$ group showed that some cells of the convoluted tubules were faintly stained with hemorrhagic areas. Testis of $\mathrm{UT}_{3}$ and $\mathrm{UT}_{4}$ groups showed decreased Leydig cells with absence of mature sperms and increased number of primary spermatocytes. Ovary of $\mathrm{UT}_{3}$ group showed reduced stroma, and those of $\mathrm{UT}_{4}$ showed highly reduced storma in the cortex and medulla of the ovary with malformed mature follicles and irregular membranes, but somewhat normal growing follicles.

Conclusion-It is clear that $4 \%$ (At the level 1.55) of the treated jojoba meal and $0.4 \%$ untreated meal give the best results.

Keyword- Treated jojoba; untreated jojoba meal; Japanese quail; Histopathological changes. 


\section{Introduction:}

Egypt is facing problems in poultry production resulting from deficiency of available protein sources used in production of poultry and animal feeds which enforced the Egyptian Government to import protein source of high prices which increased the animal feed costs and consequently the costs of animal and poultry products. Therefore, animal nutritionists in Egypt and in many developing countries are searching for other non traditional protein sources available in their countries to reduce the feed costs. In Egypt, where the irrigation water is limited and very big areas are uncultivated desert the jojoba prove to be suitable plant for desert areas and its water requirements are very limited and low. Jojoba is an oil plant and its seeds contain about $50 \%$ of oil (Wisniak ,1987). In the last years, there were considerable areas planted with jojoba especially in new villages of Sharkiya, Ismailiya and Assuit Governorates, thus jojoba helps in reclamation of new desert land, improves the soil quality and requires least amount of irrigation water. After pressing jojoba seeds to produce the oil (liquid wax) from the seeds, the remaindes materials of the seed are a cake meal containing $26-30 \%$ of protein (Verbiscar and Banigan, 1978; Verbicar et al., 1980). The resulting meal of jojoba seeds is a good source of plant protein to replace soybean meal in poultry diets; however the jojoba seed meal contains some anti-nutritional factors than simmondsin, including polyphenols, phytic acid trypsin inhibitors and bitter substances may contribute to the impaired feed intake and body weight gain of jojoba fed animal (Wiseman and Price, 1978).

\section{Social importance of jojoba:}

The jojoba plant may have potential as a soil-stabilizing plant, due to its low nutrient requirements, deep root system, drought resistance, longevity and low susceptibility to fire. As the properties of jojoba oil is same as of oil of sprum whale. Therefore the prey of whale has been reducing considerably. The oil derived from the cultivation of one-hectare jojoba is equal to oil derived from 124 whales. As this crop is free from disease there for no chemical pesticide and chemical fertilizer are needed. There for the inter crop cultivated between jojoba vacant land is free from pollution and poison and good for heath of human being. It can survive in harsh desert environments; this is so in Mexico, Israel and in Rajasthan India.

\section{http://www.jatrophabiodiesel.org /Jojoba/jojoba-uses.php \\ The present study aimed to} investigate the effect of treating the jojoba meal with bentonite, autoclaving and fungus treatment as a combined treatment to reduce the anti-nutritional effect and to detect the histopathological changes in some organs of Japanese quail (The first 
experiment) and to study the effect of low levels of untreated jojoba meal (The second experiment) and to detect any histopathological changes in Japanese quail organs.

\section{Material and methods:}

The present study was carried out in the Poultry Experimental Station belonging to the Animal Production Department, Faculty of Agriculture, AlAzhar University, Nasr City, Cairo and Animal Production Research Institute, Agricultural Research Center, Ministry of Agriculture, Egypt. The present study included two experiments, the first aimed to investigate the incorporation of treated jojoba meal seed (bentonite + autoclaving + fungus) in Japanese quail diets as replacer to soybean meal protein and to detect the histopathological changes in some organs of the Japanese quail. The second experiment was conducted to study the low levels of untreated jojoba meal on the same organs of this bird

\section{Study materials:}

Jojoba seed meal (produced by pressure and heating) was obtained from the Egyptian Natural oil Company, Cairo, Egypt.

The pure strain of Trichoderma reesei (ATCC 28217) fungus was obtained from Microbiology Research Center (MIRCEN), Faculty of Agriculture, Ain Shams University.

Bentonite was obtained from Al-Ahram for Mining and Natural Fertilizer Company, Giza, Egypt.

\section{Detoxification of jojoba meal:}

Jojoba meal used in the first experiment was exposed to detoxification treatment as follows:

1- The raw jojoba meal was mixed thoroughly with $5 \%$ bentonite powder according to Nofal et al. (2004). The mixture $(2 \mathrm{~kg})$ was kept in heat resistant polyethylene bags.

2- $2 \mathrm{~kg}$ weight mixture bags were autoclaved for $45 \mathrm{~min}$ at $121^{\circ} \mathrm{C}$ and 1.05 $\mathrm{kg} / \mathrm{cm}^{2}$ pressure (Farag, 2007).

3- Sterilized water was added to the jojoba meal bentonite mixture at a rate $10 \%$ volume to weight and mixed thoroughly, then $10 \%$ of the active liquid fungal medium was inoculated to moistened jojoba bentonite mixture (volume/weight), the mixture was kept under aerobic conditions at $28-32^{\circ} \mathrm{C}$ for 2 days, then at $24^{\circ} \mathrm{C}$ for 19 days (Abbott $\boldsymbol{e t}$ al., 1990).

4- $\quad$ After the incubation period (21 days) the treated jojoba meal was ground by hummer mill to path a $2 \mathrm{~mm}$ screen. The meal was then dried overnight in a forced air oven at $65^{\circ} \mathrm{C}$ until a constant weight and then stored in polyethylene bags until used in the experimental diets of the first experiment.

\section{Experimental diets:}

In the first experiment the treated jojoba meal was incorporated in the experimental diets to replace 0 (control); 4 $\left(\mathrm{T}_{1}\right) ; 8\left(\mathrm{~T}_{2}\right)$ and $12 \%\left(\mathrm{~T}_{3}\right)$ of soybean meal protein. The experimental diets in the first experiment were formulated to contain 
almost $24 \%$ crude protein and $2900 \mathrm{kcal}$ $\mathrm{ME} / \mathrm{kg}$ diet. All experimental diets were formulated to be isonitrogenous and isocaloric.

The composition of the experimental diets (Experiment 1) are presented in table (1) and calculated according to NRC (1994).

In the second experiment, raw jojoba seed meal was added at the levels 0 ; $0.2 ; 0.4 ; 0.6$ and 0.8 as feed additives untreated.

\section{Experimental birds:}

In the first experiment a total number of 192 one week old unsexed Japanese quail chicks were allotted in four dietary treatments 48 birds each. Each treatment was performed in three replicates 16 birds each. The experiment included 12 replicates representing four dietary treatments. All the experimental birds were healthy and free of pathogens. Food and water were offered throughout the experimental period which lasted five weeks after start.

For the second experiment, the control diet and the quail group in the first experiment was used in the second experiment. The dietary treatment groups were fed the control diet supplemented with $0.2 ; 0.4 ; 0.6$ and $0.8 \%$ of untreated jojoba seed meal. For these treatments a total number of 192 Japanese quail unsexed healthy one week old were used. The chicks were randomly divided into four dietary treatments 48 bird each divided in three replicates each (16 bird each). Birds of the second experiment lasted 5 weeks after start.

At the end of the 5 week (The experimental period) three male and three female of Japanese quail birds from each experimental group were randomly selected. Small pieces of liver, ileum, kidney tests and ovary were removed immediately after decapitation and fixed in $10 \%$ neutral buffer formol ,washed, dehydrated as usual in ascending grades of ethyl alcohol, cleared in xylol embedded in paraffin was and sectioned at five microns. Sections were stained with haematoxylin and eosin (Carleton, 1980) and then subjected for the light microscopy examination.

\section{$\underline{\text { Results }}$}

Tables (1\&2) showing classification of the different experimental groups and composition and calculated analysis of the experimental diets.

The microscopic examination of liver of the control group of Japanese quail is shown in figs. ( $1 \& 2)$; ileum in fig. (3); kidney in fig. (4); testis in fig (5) and ovary in fig. (6).

\section{Experiment 1:}

Liver of group $\left(T_{1}\right)$ showed dilated and corrugated wall of the hepatic portal vein which contained haemolysed blood cells (Figs.7\&8).Liver of group $\left(\mathrm{T}_{2}\right)$ showed numerous pathological changes in the central `and portal areas (Figs. 9\&10) such as: dilated sinusoidal spaces, some were congested, ruptured endothelial lining, of the central vein, corrugated wall of the hepatic portal vein (hpv), fibrotic arterial 
wall with some vacuolated hepatocytes. Liver of group $\left(T_{3}\right)$ showed highly elongated wall of the hepatic portal vein (hpv), thickened arterial walls, elongated walls of the bile ducts, haemolysed blood cells inside the hepatic portal vein (Fig. 11).

Ileum of group $\left(\mathrm{T}_{1}\right)$ showed few ruptured villi (Fig. 12). Ileum of group $\left(\mathrm{T}_{2}\right)$ showed highly thickened muscle layer, ruptured villi with disturbed architecture of the villi (Fig. 13). Ileum of group $\left(\mathrm{T}_{3}\right)$ showed highly affected and reduced villi, some of them were ruptured with thin corrugated and malformed muscle fibers (Fig. 14). Kidney of group $\left(\mathrm{T}_{1}\right)$ showed somewhat normal appearance (Fig. 15). Kidney of group $\left(T_{2}\right)$ showed that most golmeruli were faintly stained with congested intertubular spaces (Fig. 16). Kidney of group $\left(\mathrm{T}_{3}\right)$ showed normal appearance of the golmeruli, convoluted tubules, but congested and dilated blood vessels were still detected (Fig. 17).

Testes of group $\left(\mathrm{T}_{1}\right)$ showed normal architecture (Fig. 18). Testis of group $\left(\mathrm{T}_{2}\right)$ showed hypocellularity of spermatogenic layers with absences of mature sperms (Fig. 19). Testis of group $\left(\mathrm{T}_{3}\right)$ showed hypocellularity of spermatgenic layers and their cells with absence of mature sperms (Fig. 20).Ovary of group $\left(\mathrm{T}_{1}\right)$ showed normal growing follicles (Fig. 21), ovary of group $\left(\mathrm{T}_{2}\right)$ showed normal follicles with their membranes (Fig. 22). Ovary of group $\left(\mathrm{T}_{3}\right)$ showed somewhat normal ovum with reduced internal content, growing follicles showed normal appearance (Fig. 23).

\section{Experiment 2:}

Liver of group ( $\mathrm{UT}_{1}, \mathrm{UT}_{2}$ and $\left.\mathrm{UT}_{3}\right)$ showed normal structure. Liver of group $\left(\mathrm{UT}_{4}\right)$ showed somewhat normal architecture (Figs. 24 and 25).

Ileum of group ( $\mathrm{UT}_{1}$ and $\left.\mathrm{UT}_{2}\right)$ showed normal structure. Ileum of group $\left(\mathrm{UT}_{3}\right.$ and $\mathrm{UT}_{4}$ ) showed somewhat normal appearance (Figs. 26 and 27).Kidney of groups ( $\mathrm{UT}_{1}$ and $\mathrm{UT}_{2}$ ) showed normal structure. Kidney of group $\left(\mathrm{UT}_{3}\right)$ showed that some distal convoluted tubules were faintly stained (Fig. 28). Kidney of group $\left(\mathrm{UT}_{4}\right)$ showed faintly stained cells of the distal convoluted tubules with hemorrhagic areas and congested blood vessels (Fig. 29).

Testes of groups ( $\mathrm{UT}_{1}$ and $\mathrm{UT}_{2}$ ) showed normal structure. Testes of groups $\left(\mathrm{UT}_{3}\right.$ and $\mathrm{UT}_{4}$ ) showed highly decreased Leydig cells with absence of mature sperms and increased number of primary spermatocytes (Figs. $30 \& 31$ ).

$$
\text { Ovary of group }\left(\mathrm{UT}_{1}\right) \text { showed }
$$

normal structure. Ovary of group ( $\left.\mathrm{UT}_{2}\right)$ showed growing follicles with normal appearance (Fig. 32) and showed mature ovum with reduced internal contents (Fig. 33). Ovary of group $\left(\mathrm{UT}_{3}\right)$ showed normal growing follicles (Fig. 34) and showed increased stroma (Fig. 35). Ovary of group $\left(\mathrm{UT}_{4}\right)$ showed somewhat normal growing follicle (Fig.36), malformed mature follicles with irregular membranes and highly reduced internal content (Fig. 37), highly reduced stroma in the cortex and medulla of 
the

ovary

(Fig.38).

\section{Discussion}

Jojoba (Simmondsia chinensis) is belonging to Family: Simmondsiaceae Order:Caryophyllales,Genus:

Simmondsia and Species:Chinensis. Jojoba (Simmondsia chinensis) is belonging to Family: Simmondsiaceae Order Caryophyllales,Genus: Simmondsia and Species: Chinensis..

Jojoba is a shrub native to the Sonoran and Mojave deserts of Arizona, California, and Mexico. It is the sole species of the family Simmondsiaceae. It is also known as goat nut, deer nut, pignut, the soil profile so drought conditions can be tolerated. In the desert $(<100 \mathrm{~mm}$ rain/year) the plants persist as small stunted bushes and survive temperatures of $45^{\circ} \mathrm{C}$. Under more favorable conditions the plants thrive and potentially have a life span exceeding 100 years. The plant normally flowers in spring after the autumn/winter rains. Ideal conditions for growth are annual rainfall of $500-600 \mathrm{~mm}$ and flat areas that are less than $350 \mathrm{~m}$ above sea level. The plant is dioecious (female and male flowers are found on separate bushes). Male flowers form small yellow balls; female flowers are green and inconspicuous and are wind pollinated. The seeds, after ripening and harvest in the summer, are crushed and give a liquid wax yield of about $50 \%$ by weight. The product which is traded is called jojoba oil, potential world production of this product is currently around 3,500 metric wild hazel, quinine nut, coffeeberry, and gray box bush. Jojoba is grown commercially for its oil, a liquid wax ester, extracted from the seed. The plant has also been used to combat and prevent desertification in the Thar Desert in India (Steven et al., 2000). Jojoba is a small perennial evergreen woody tree or shrub that ranges from $0.5-6 \mathrm{~m}$ (but usually 2 $2.5 \mathrm{~m}$ ) in height with a tap root that is able to penetrate $15-25 \mathrm{~m}$ below the soil surface. The plants are well adapted to desert conditions, originating from the Sondran and Baja deserts (USA). The deep rooting system is able to extract water from deep in tones per year, the major production areas being; USA, Mexico, Costa Rica, Australia, Brazil and Paraguay. Commercial plantations also exist in Argentina, Egypt, Israel and Peru .Jojoba is currently not sufficiently domesticated for commercial production in Europe, research is continuing in Southern European countries, including France, Italy, Spain, Greece and Portugal to investigate the potential for successful production. Research is being carried out relating to plant exploration and evaluation along with crop improvement and breeding techniques.

In order to optimize production and yields of jojoba further research is required in the following areas; weed control, nutrition, varietal selection and harvesting equipment.

Jojoba meal has been incorporated into feed rations of broilers in Belgium, it is 
thought that $4 \%$ of jojoba meal in the feed restricts the feed intake level to give a favorable muscle to fat ratio, this eliminates over fat birds. This strategy is being tried in other animal species in an attempt to achieve the same effect (Forster and Wright, 2009).

The histopathological results observed in liver of treated jojoba meal groups in this study are in agreement with those of Farag (2007).She reported that liver of broiler fed $3 \%$ jojoba protein treated meal showed large area of mononuclear cell aggregations. In broilers fed $10 \%$ jojoba protein treated meal showed an excess mononuclear cell infiltration. Similar changes of cellular mononuclear cell aggregations were seen broilers fed $17 \%$ and $24 \%$ jojoba protein treated meal.

Sobhy et al. (2003) noticed minimal histopathological changes in liver of rats fed on 5 or $10 \%$ detoxified jojoba meal. Numerous changes were observed in ileum of the different treated groups of this study are in agreement with those of Farag (2007). She noticed that in broilers fed 3\% jojoba protein treated meal the intestinal villi were thick with a hyperplastic and vacuolated covering epithelium. She added that the crypts of the intestinal glands, after treatment in broilers fed $10 \%$ jojoba protein treated meal contained excess of mononuclear cell infiltration; while broilers fed $17 \%$ jojoba protein treated meal some of the degenerated crypts of the intestinal glands appeared cystic and filled with some necrotic debris. Broilers fed $24 \%$ jojoba protein treated meal showed some variable sized areas of mononuclear cell aggregations in the submucosa, while Sobhy et al. (2003) noticed minimal histopathological changes of intestine in rats fed on 5 or $10 \%$ detoxified jojoba meal.

Numerous changes were detected in kidney tissue of treated jojoba meal groups in this study; these changes are in accordance with those of Sobhy et al. (2003) and Farag (2007). Farag (2007) reported that kidneys of broilers fed 3\% jojoba protein treated meal showed congestion of the intertubular blood capillaries. Broilers fed $10 \%$ jojoba protein treated meal showed extensive congestion for the intertubular blood vessels. The microscopic observation of the kidneys of broilers fed $17 \%$ jojoba protein treated meal showed swollen epithelium of the renal tubules with vacuolar degeneration in the epithelium. In the broilers fed $24 \%$ jojoba protein treated meal; the renal tubules appeared to be completely damaged and necrotic, while Sobhy et al. (2005) showed minimal histopathological changes of kidney of rats fed on 5 or $10 \%$ detoxified jojoba meal. Ovarian changes observed in this study was also observed by Sobhy et al. (2003).They noticed minimal histopathological changes in the testis of rats fed 5 or $10 \%$ detoxified jojoba meal. Liver of group $\left(\mathrm{UT}_{1}, \mathrm{UT}_{2}\right.$ and $\mathrm{UT}_{3}$ ) showed normal structure. Liver of group $\left(\mathrm{UT}_{4}\right)$ showed somewhat normal architecture. These results are in agreement 
with those of Cokelaere et al. (1993). They observed normal structure of liver of weanling rats fed $3 \%$ of untreated defatted jojoba meal in food. Also, these results are in harmony with the results of Boozer and Herron (2006) who observed that there were no remarkable histopathological changes in the liver of rats received 0.015 , 0.05 and $0.15 \%$ simmondsin. On the other hand, Cokelaere et al. (1993) showed that rats fed on food with $3 \%$ defatted jojoba meal revealed vasodilatation of most of the vasculature with various degenerative changes in the intestine, liver, kidneys and testes. In rat fed on food with $6 \%$ defatted jojoba meal, the small intestine showed severe degeneration in the lining intestinal epithelium with catarrhal enteritis. Minimal histopathological changes were seen in rats fed on 5 or $10 \%$ detoxified jojoba meal.

Sobhy et al. (2003) showed that rats fed on food with $3 \%$ defatted jojoba meal revealed vasodilatation of most of the vasculature with various degenerative changes in the liver.

Ileum of group ( $\mathrm{UT}_{1}$ and $\left.\mathrm{UT}_{2}\right)$ showed normal structure. Ileum of group $\left(\mathrm{UT}_{3}\right.$ and $\left.\mathrm{UT}_{4}\right)$ showed somewhat normal appearance. These results are in harmony with results of Cokelaere et al. (1993) .They noticed normal structure of ileum of weanling rats fed $3 \%$ untreated defatted jojoba meal in the food. On the other hand, Sobhy et al. (2003) showed that rats fed on food with $3 \%$ defatted jojoba meal revealed vasodilatation of most of the vasculature with various degenerative changes in the intestine. In rat fed on food with $6 \%$ defatted jojoba meal, the small intestine showed severe degeneration in the lining intestinal epithelium with enteritis.

Kidney of groups ( $\mathrm{UT}_{1}$ and $\mathrm{UT}_{2}$ ) showed normal structure. Kidney of group $\left(\mathrm{UT}_{3}\right)$ showed that some distal convoluted tubules were faintly stained. Kidney of group $\left(\mathrm{UT}_{4}\right)$ showed faintly stained cells of the distal convoluted tubules with hemorrhagic areas and congested blood vessels These results in agreement with those reported by Sobhy $\boldsymbol{e t}$ al. (2003) .They noticed that rats fed on food with $3 \%$ defatted jojoba meal revealed vasodilatation of most of the vasculature with various degenerative changes in the kidneys.

While, Boozer and Herron (2006) observed that there were no remarkable histopathological changes in kidney. In the same direction, Cokelaere et al. (1993) showed normal structure of kidney of weanling rats fed $3 \%$ of untreated defatted jojoba meal in the food. Furthermore, ELAnany (2007) reported that kidney tissues of rats administered a diet containing 15\% of jojoba meal protein isolate for 8 weeks, showed the same histological character as the control rats.

Testes of groups ( $\mathrm{UT}_{1}$ and $\mathrm{UT}_{2}$ ) showed normal structure. Testes of groups $\left(\mathrm{UT}_{3}\right.$ and $\left.\mathrm{UT}_{4}\right)$ showed highly decreased Leydig cells with absence of mature sperms and increased number of primary spermatocytes.These results are in 
agreement with those of Sobhy et al. ( 2003) ,they showed that rats fed on food with 3\% defatted jojoba meal revealed vasodilatation of most of the vasculature with various degenerative changes in the testes.

Ovary of group $\left(\mathrm{UT}_{1}\right)$ showed normal structure. Ovary of group $\left(\mathrm{UT}_{2}\right)$ showed growing follicles with normal appearance and showed mature ovum with reduced internal contents. Ovary of group $\left(\mathrm{UT}_{3}\right)$ showed normal growing follicles (Fig. 34) and showed increased stroma (Fig. 35). Ovary of group ( $\left.\mathrm{UT}_{4}\right)$ showed somewhat normal growing follicle malformed mature follicles with irregular membranes and highly reduced internal content, highly reduced stroma in the cortex and medulla of the ovary.

Conclusion- It is clear that $4 \%$ ( At the level 1.55) of the treated jojoba meal and $0.4 \%$ untreated meal gives the best results.

. Further investigations are needed to detect the suitable levels of untreated and treated jojoba meals to avoid the histopathological changes observed in this study especially in Leydig cells which affect the fertility.

Table (1): showing classification of the different experimental groups Experiment I

Experiment II

\begin{tabular}{|c|c|c|c|c|c|c|c|}
\hline \multirow[t]{2}{*}{ Control (C) } & \multicolumn{3}{|c|}{ Treated JM to replaced protein } & \multicolumn{4}{|c|}{ Untreated JM as supplement } \\
\hline & $\mathrm{T}_{1}(4 \%)$ & $\mathrm{T}_{2}(8 \%)$ & $\mathrm{T}_{3}(12 \%)$ & $\begin{array}{l}\mathrm{UT}_{1} \\
(0.2 \%)\end{array}$ & $\begin{array}{r}\mathrm{UT}_{2} \\
(0.4 \%)\end{array}$ & $\begin{array}{r}\mathrm{UT}_{3} \\
(0.6 \%)\end{array}$ & $\begin{array}{l}\mathrm{UT}_{4} \\
(0.8 \%)\end{array}$ \\
\hline
\end{tabular}

Table (2): showing the composition and calculated analysis of the experimental diets. 


\begin{tabular}{|l|c|c|c|c||}
\hline \multirow{2}{*}{ Ingredients } & \multicolumn{4}{|c||}{ Treated jojoba meal substitution levels } \\
\cline { 2 - 5 } & $\mathbf{0 \%}$ & $\mathbf{4 \%}$ & $\mathbf{8 \%}$ & $\mathbf{1 2 \%}$ \\
\hline Yellow corn & 54.39 & 54.18 & 53.96 & 53.78 \\
Soybean meal (44\%) & 30.00 & 28.80 & 27.60 & 26.40 \\
Treated jojoba meal & - & 1.55 & 3.10 & 4.65 \\
Corn gluten meal (62\%) & 8.53 & 8.5 & 8.48 & 8.44 \\
Wheat bran (15.7) & 3.45 & 3.45 & 3.45 & 3.45 \\
Cotton seed oil & 0.37 & 0.25 & 0.13 & - \\
Limestone & 1.33 & 1.31 & 1.29 & 1.24 \\
Dicalcium phosphate & 0.89 & 0.89 & 0.89 & 0.89 \\
Common salt & 0.30 & 0.30 & 0.30 & 0.30 \\
Premix* & 0.30 & 0.30 & 0.30 & 0.30 \\
Choline chloride & 0.10 & 0.10 & 0.10 & 0.10 \\
Dl-Methionine & 0.09 & 0.09 & 0.10 & 0.11 \\
L-Lysine & 0.25 & 0.28 & 0.30 & 0.33 \\
\hline \hline \multicolumn{1}{|c|}{ Total } & 100 & 100 & 100 & 100 \\
\hline Calculated analysis** & & & & \\
Crude protein; \% & 24.006 & 24.006 & 24.005 & 24.008 \\
M.E., Kcal/kg & 2900.23 & 2900.30 & 2900.31 & 2900.84 \\
Crude fiber; \% & 3.787 & 3.882 & 3.976 & 4.072 \\
Calcium, \% & 0.804 & 0.807 & 0.810 & 0.801 \\
A.ph. \% & 0.310 & 0.308 & 0.306 & 0.304 \\
Methionine, \% & 1.307 & 1.309 & 1.302 & 1.304 \\
Lysine, \% & 0.509 & 0.501 & 0.503 & 0.505 \\
\hline Price per ton & 2464.65 & 2440.90 & 2419.45 & 2399.30 \\
\hline \hline
\end{tabular}

* Each $3 \mathrm{~kg}$ of premix contained : Vit. A 12000000 I.U., Vit D3 2000000 I.U., Vit E $10000 \mathrm{mg}$, Vit $\mathrm{K}_{3} 2000 \mathrm{mg}$, Vit $\mathrm{B}_{1} 1000 \mathrm{mg}$, Vit $\mathrm{B}_{2} 5000 \mathrm{mg}$, vit $\mathrm{B}_{6} 1500 \mathrm{mg}$, Vit $\mathrm{B}_{12}$ 10mg, Pantothenic acid $10000 \mathrm{mg}$, Niacin $30000 \mathrm{mg}$, folic acid $1000 \mathrm{mg}$, Biotin $50 \mathrm{mg}$, , Ma 60000mg, Zn 50000 mg, Cu 10000mg, Fe 30000mg, Id 1000mg, Se 100 mg, Co $100 \mathrm{mg}$ and $\mathrm{CaCo}_{2}$ to $3 \mathrm{~kg}$.

** According to NRC (1994). 

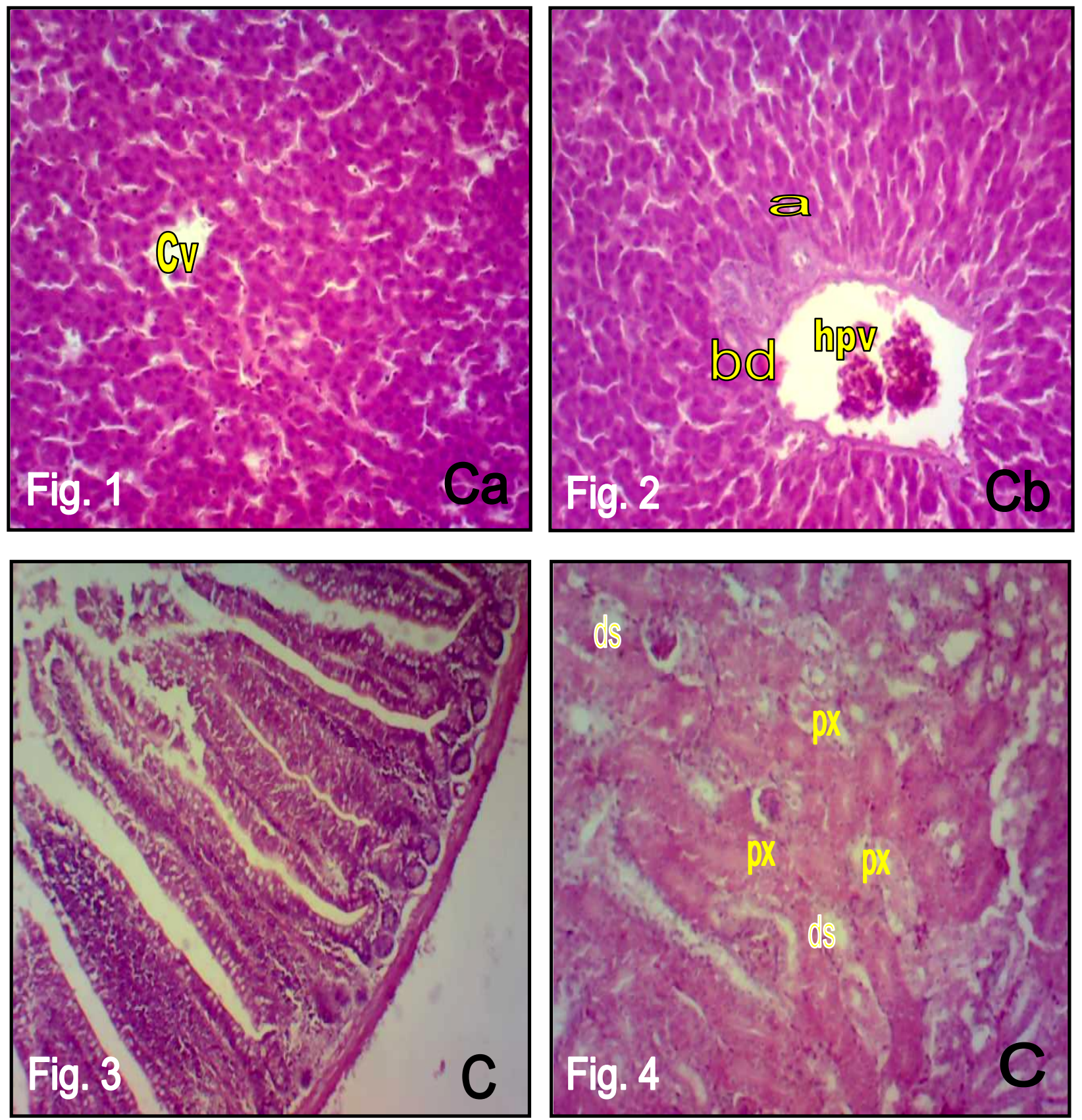

Fig. (1): Liver of the control Japanese quail (C) showing cords of hepatocytes radiating from the central vein $(\mathrm{cv})$. (H\&E x 100).

Fig. (2): Liver of the control Japanese quail (C) showing the hepatic portal area which contains a branch of the hepatic portal vein (hpv), a branch of the hepatic artery (a) and bile ducts (bd)

Fig. (3): Ileum of the control Japanese quail (C) showing normal structure of the ileum.

Fig. (4): kidney of the control Japanese quail (C) showing the normal structure. Notice: glomeruli with their Malpighian capsules, proximal (px) and distal (ds) convoluted tubules. 

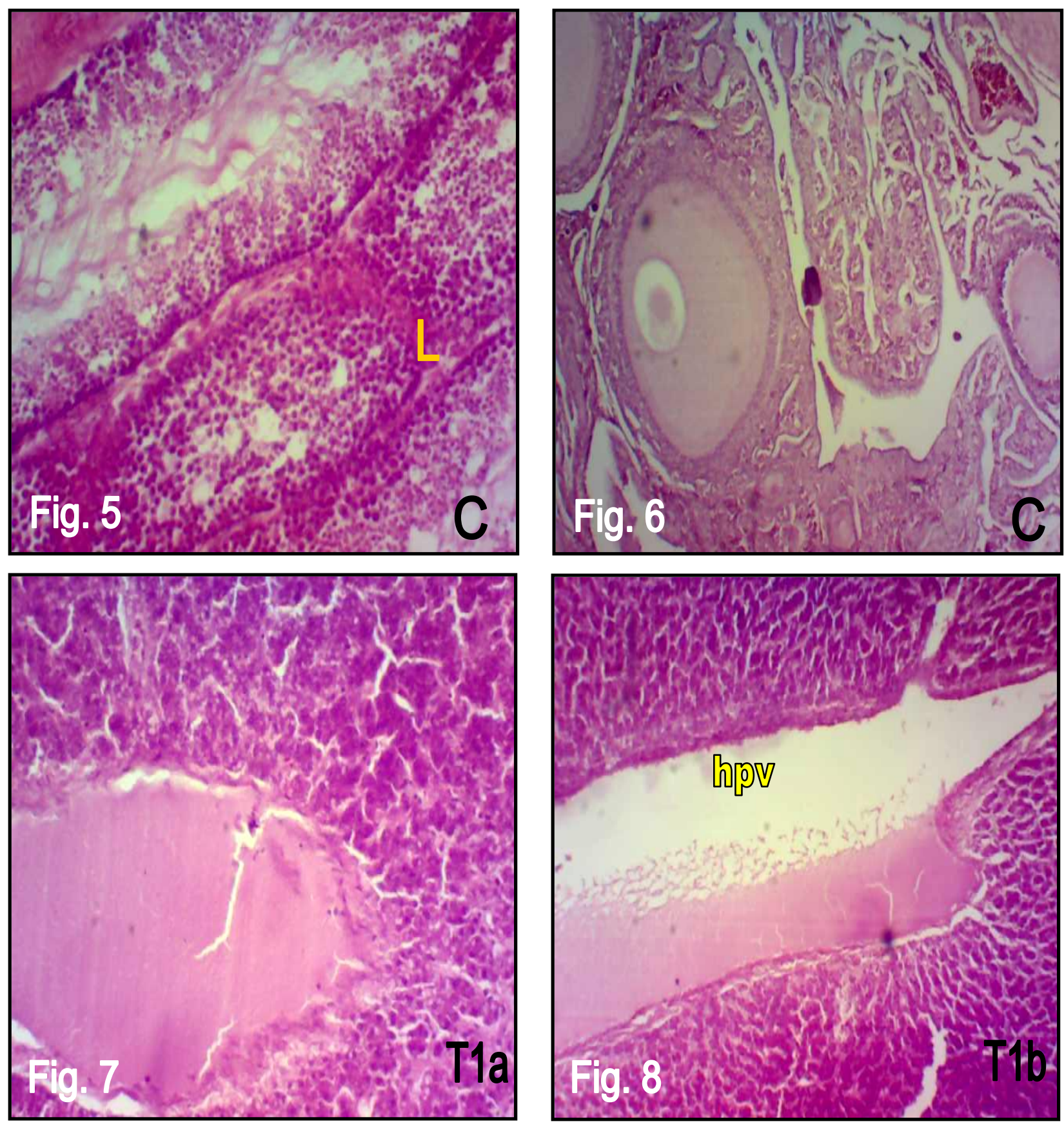

Fig. (5): Testis of the control Japanese quail (C) showing well developed spermatogenic cells and layers in the seminiferous tubules of a control testis and Leydig cells (L).

Fig. (6): Ovary of the control Japanese quail (C) showing normal growing ova.

Fig. (7): Liver of Japanese quail fed diet containing $4 \%$ treated jojoba meal protein $\left(\mathrm{T}_{1}\right)$, showing dilated walls of central and hepatic portal veins which contained haemolysed blood cells.

Fig. (8): Liver of Japanese quail fed diet containing $4 \%$ treated jojoba meal protein $\left(\mathrm{T}_{1}\right)$, showing corrugated wall of the hepatic portal vein which contained haemolysed blood cells 

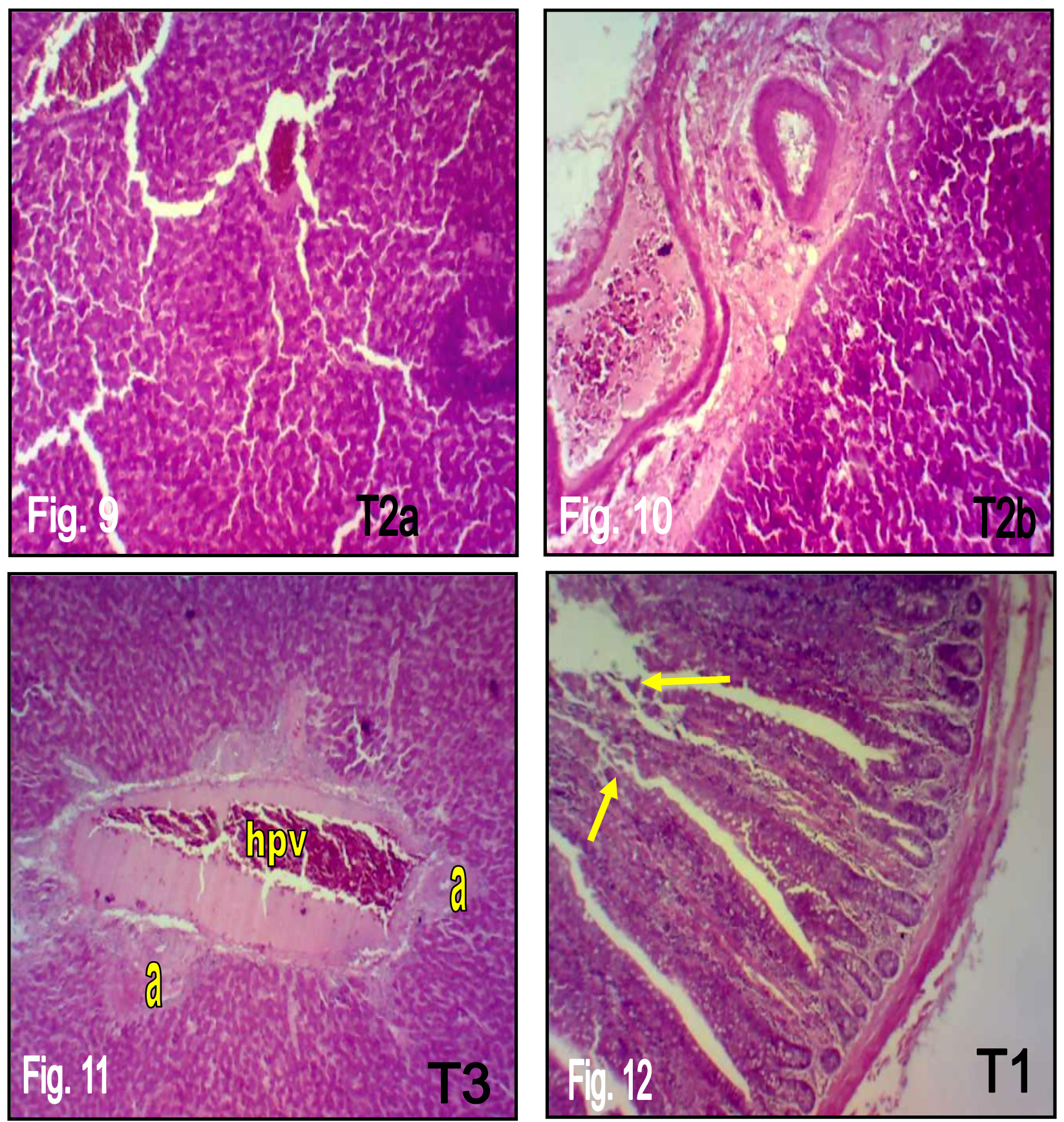

Fig. (9): Liver of Japanese quail fed diet containing $8 \%$ treated jojoba meal protein $\left(\mathrm{T}_{2}\right)$, showing numerous pathological changes in the central and portal areas.

Fig. (10): Liver of Japanese quail fed diet containing $8 \%$ treated jojoba meal protein $\left(\mathrm{T}_{2}\right)$, showing dilated sinusoidal spaces; some were congested, ruptured endothelial lining of the central vein, corrugated wall of the hepatic portal vein, fibrotic arterial wall with some vacuolated hepatocytes.

Fig. (11): Liver of Japanese quail fed diet containing $12 \%$ treated jojoba meal protein $\left(\mathrm{T}_{3}\right)$, showing highly elongated wall of hepatic portal vein, thickened arterial walls (a), elongated walls of the bile ducts, haemolysed blood cells inside the hepatic portal vein.

Fig. (12): Ileum of Japanese quail fed diet containing $4 \%$ treated jojoba meal protein $\left(\mathrm{T}_{1}\right)$, showing Showing few ruptured villi( $\uparrow)$. 

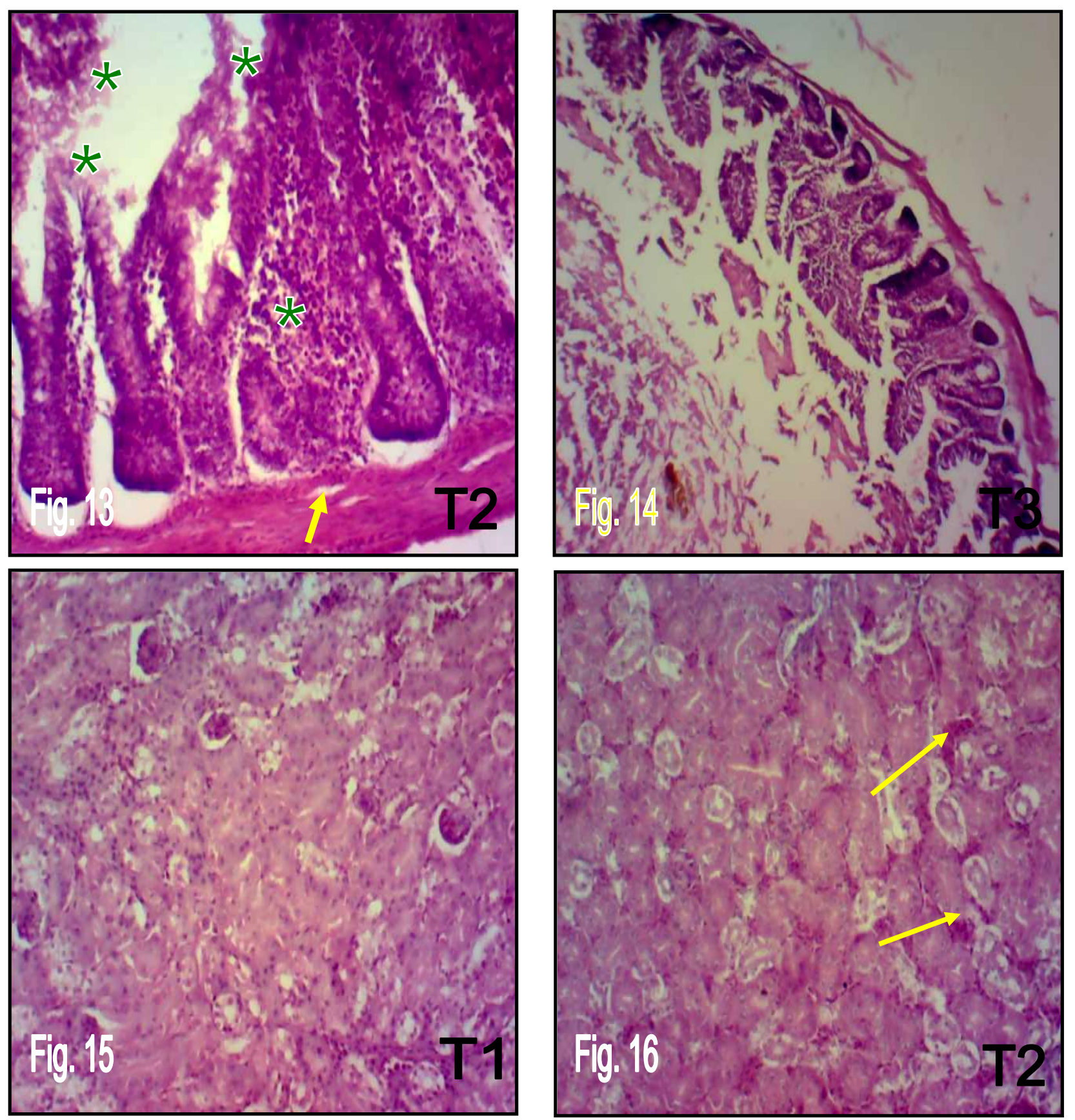

Fig. (13): Ileum of Japanese quail fed diet containing $8 \%$ treated jojoba meal protein $\left(\mathrm{T}_{2}\right)$, showing highly thickened muscle layer $(\uparrow)$, ruptured villi $(*)$ with disturbed architecture of them .

Fig. (14): Ileum of Japanese quail fed diet containing $12 \%$ treated jojoba meal protein $\left(\mathrm{T}_{3}\right)$, showing highly affected ileum tissue with highly reduced villi ,some of them were ruptured, thin, corrugated with malformed muscle fibers.

Fig. (15): Kidney of Japanese quail fed diet containing $4 \%$ treated jojoba meal protein $\left(\mathrm{T}_{1}\right)$, showing somewhat normal appearance.

Fig. (16): Kidney of Japanese quail fed diet containing $8 \%$ treated jojoba meal protein $\left(\mathrm{T}_{2}\right)$, showing that most golmeruli were faintly stained with congested intertubular spaces $(\uparrow)$. 

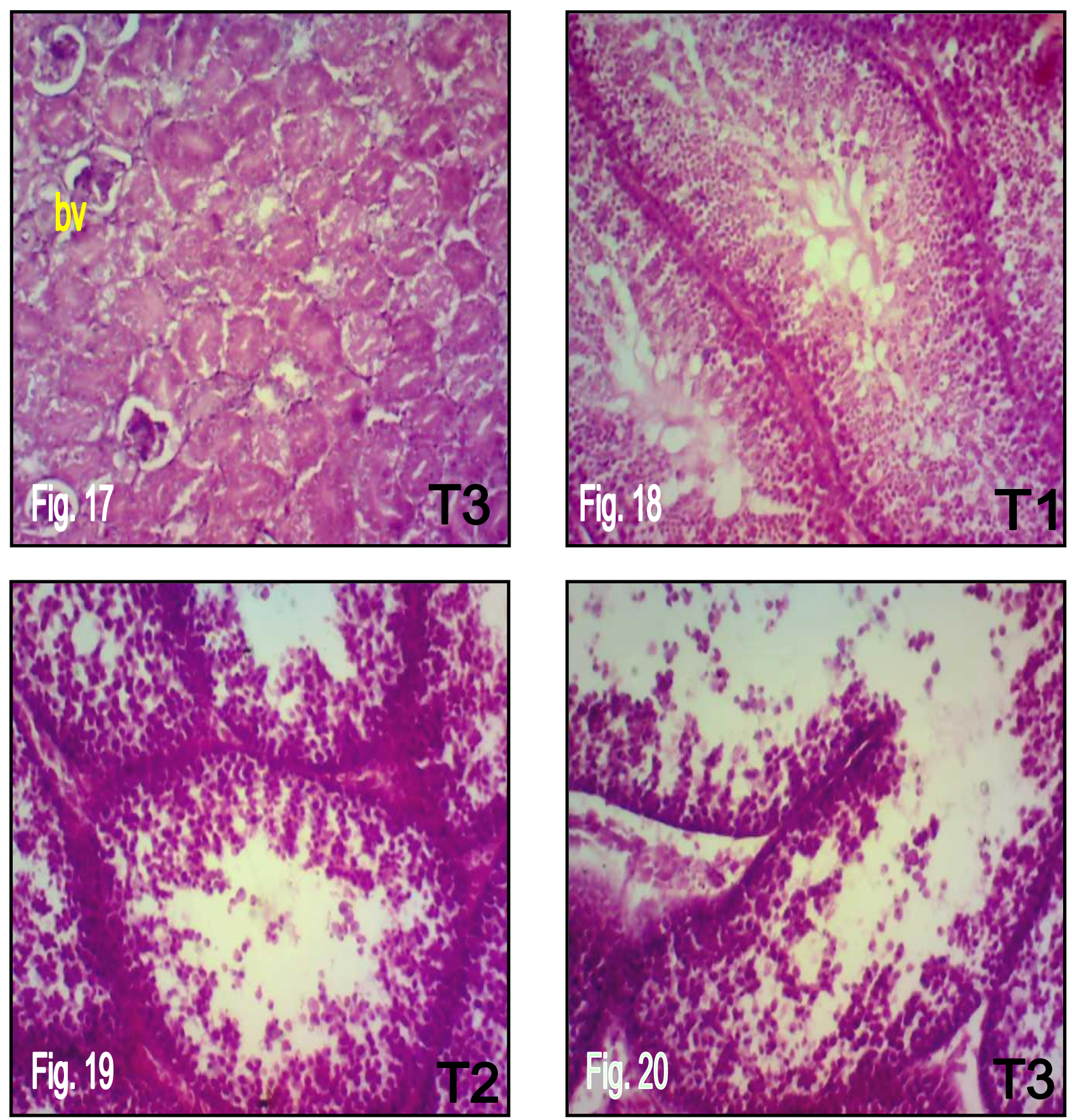

Fig. (17): Kidney of Japanese quail fed diet containing $12 \%$ treated jojoba meal protein $\left(\mathrm{T}_{3}\right)$, showing normal appearance of glomeruli, convoluted tubules, but congested and dilated blood vessels (bv) were still detected.

Fig. (18): Testis of Japanese quail fed diet containing $4 \%$ treated jojoba meal protein $\left(\mathrm{T}_{1}\right)$, showing normal architecture of testis tissue.

Fig. (19): Testis of Japanese quail fed diet containing $8 \%$ treated jojoba meal protein $\left(\mathrm{T}_{2}\right)$, showing hypocellularity of spermatogenic layers and their cells with absence of mature sperms.

Fig. (20): Testis of Japanese quail fed diet containing $12 \%$ treated jojoba meal protein $\left(\mathrm{T}_{3}\right)$, showing hypocellularity of spermatogenic layers and their cells with absence of mature sperms. 

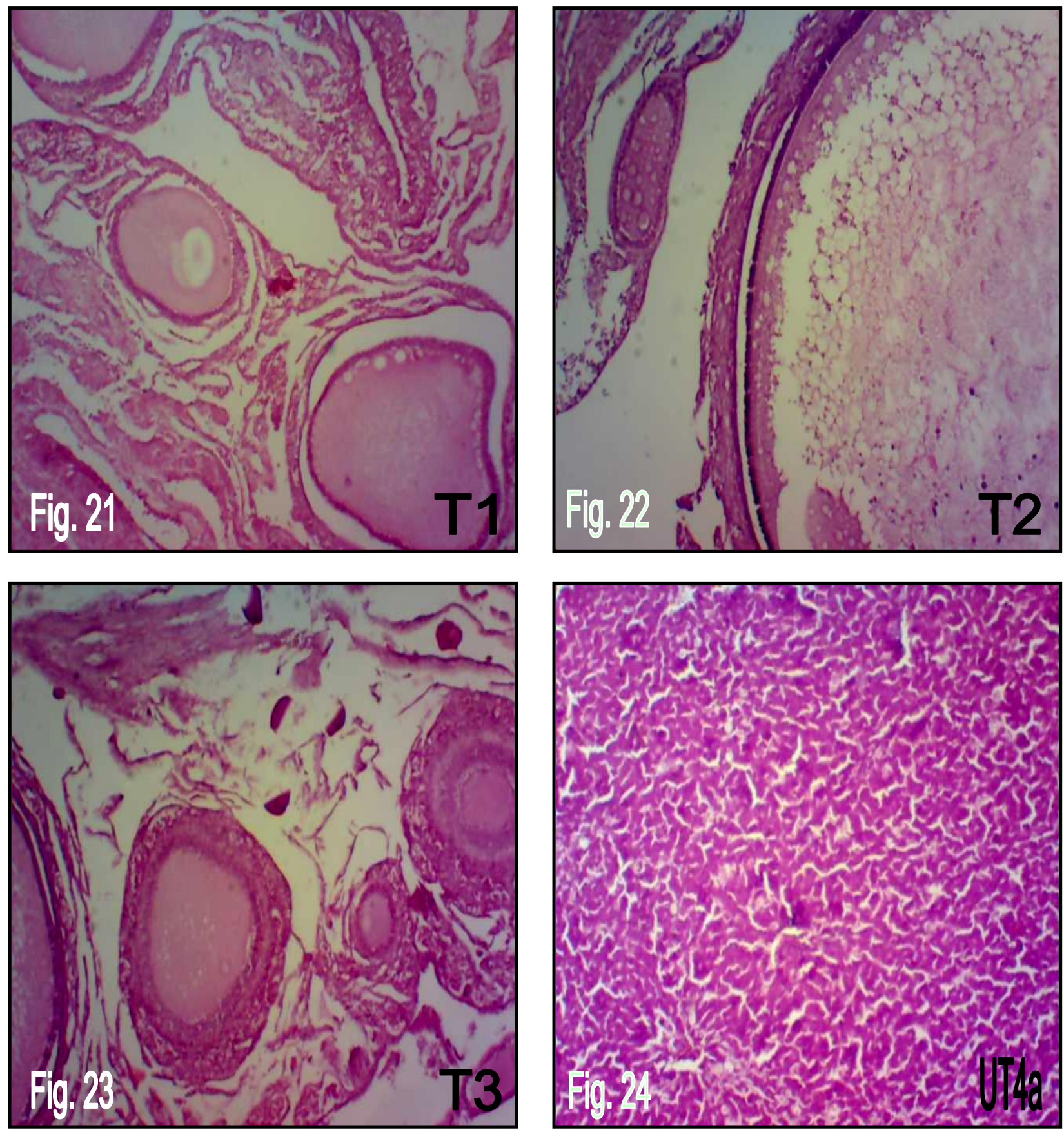

Fig. (21): Ovary of Japanese quail fed diet containing 4\% treated jojoba meal protein (T1), showing normal growing follicles.

Fig. (22): Ovary of Japanese quail fed diet containing $8 \%$ treated jojoba meal protein (T2), showing normal follicles with their membranes.

Fig. (23): Ovary of Japanese quail fed diet containing $12 \%$ treated jojoba meal protein $\left(\mathrm{T}_{3}\right)$, showing somewhat normal mature ovum with reduced internal content, growing follicles showed normal appearance.

Fig. (24): Liver of Japanese quail fed diet supplied with $0.8 \%$ untreated jojoba meal protein $\left(\mathrm{UT}_{4}\right)$, showing somewhat normal architecture. 
Abd El-Hakim ,N.F et al
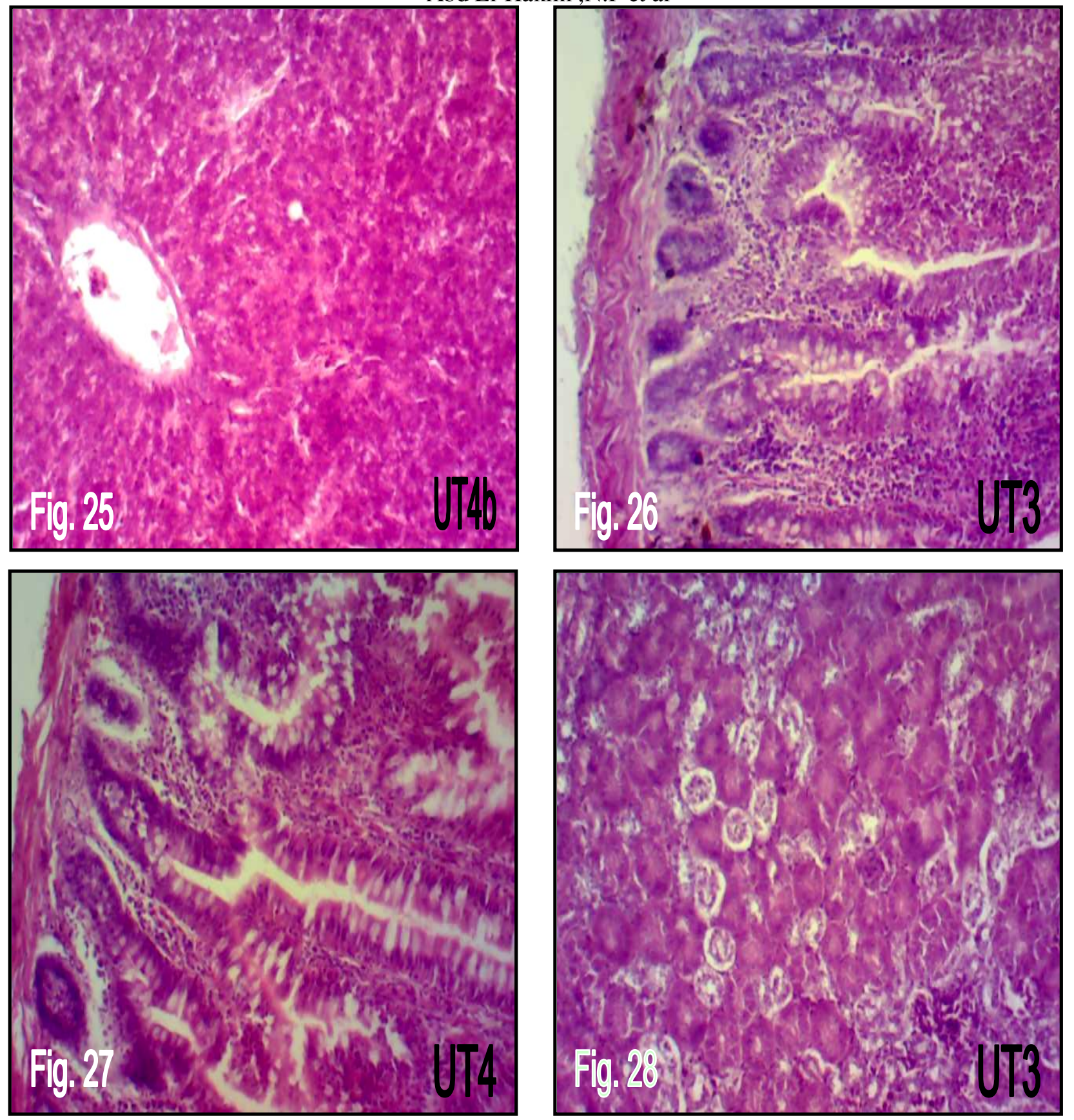

Fig. (25): Liver of Japanese quail fed diet supplied with $0.8 \%$ untreated jojoba meal protein $\left(\mathrm{UT}_{4}\right)$, showing somewhat normal architecture.

Fig. (26): Ileum of Japanese quail fed diet supplied with $0.6 \%$ untreated jojoba meal protein $\left(\mathrm{UT}_{3}\right)$, showing somewhat normal appearance.

Fig. (27): Ileum of Japanese quail fed diet supplied with $0.8 \%$ untreated jojoba meal protein $\left(\mathrm{UT}_{4}\right)$, showing somewhat normal appearance.

Fig. (28): Kidney of Japanese quail fed diet supplied with $0.6 \%$ untreated jojoba meal protein $\left(\mathrm{UT}_{3}\right)$, showing that some distal convoluted tubules were faintly stained. 

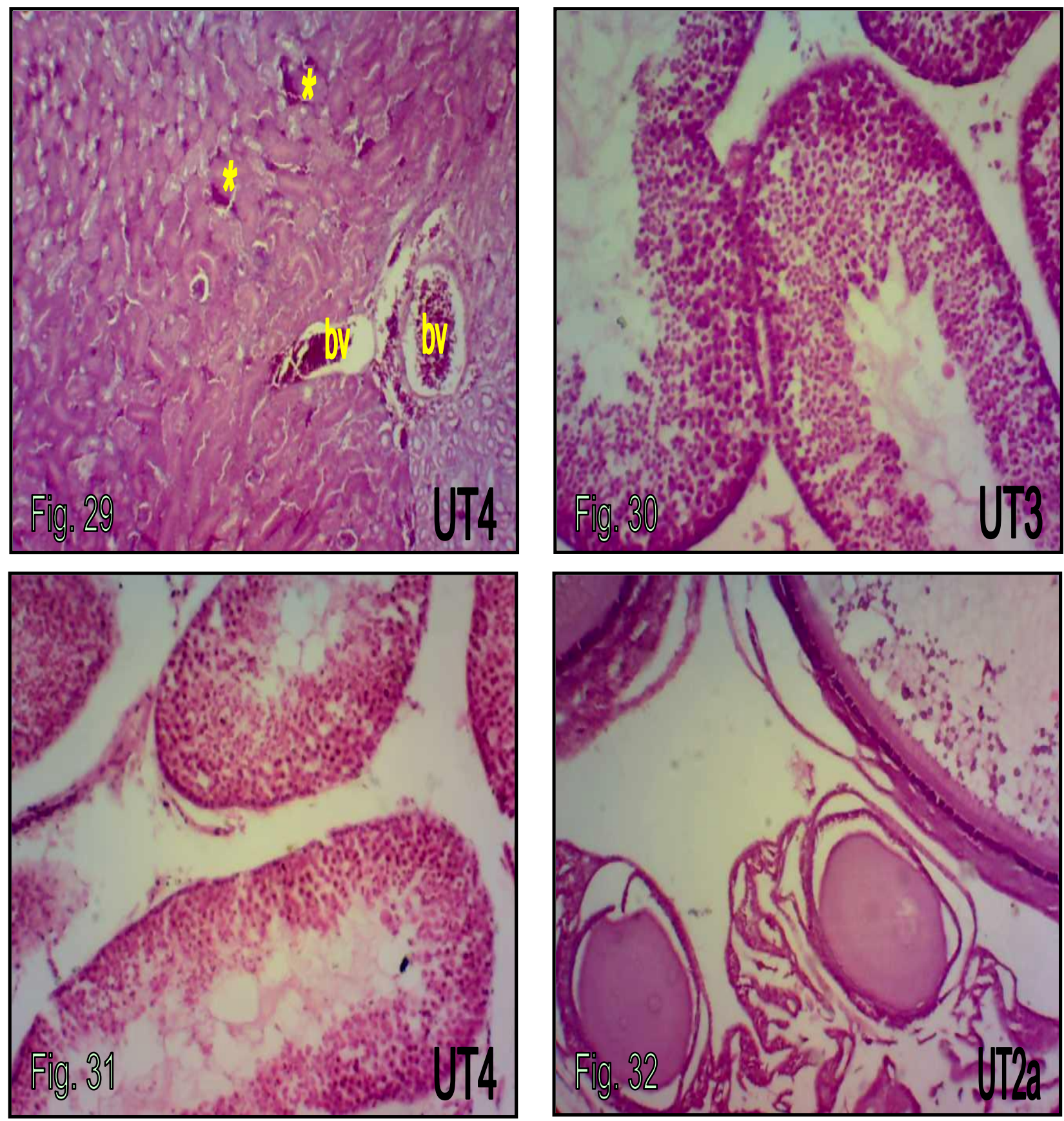

Fig. (29): Kidney of Japanese quail fed diet supplied with $0.8 \%$ untreated jojoba meal protein $\left(\mathrm{UT}_{4}\right)$, showing faintly stained cells of distal convoluted tubules with hemorrhagic areas $(*)$ and congested blood vessels (bv).

Fig. (30): Testis of Japanese quail fed diet supplied with $0.6 \%$ untreated jojoba meal protein $\left(\mathrm{UT}_{3}\right)$, showing highly decreased Leydig cells with absence of mature sperms and increased number of primary spermatocytes.

Fig. (31): Testis of Japanese quail fed diet with $0.8 \%$ untreated jojoba meal protein $\left(\mathrm{UT}_{4}\right)$, showing highly decreased Leydig cells with absence of mature sperms and increased number of primary spermatocytes.

Fig. (32): Ovary of Japanese quail fed diet supplied with $0.4 \%$ untreated jojoba meal protein $\left(\mathrm{UT}_{2}\right)$, showing growing follicles with normal appearance. 

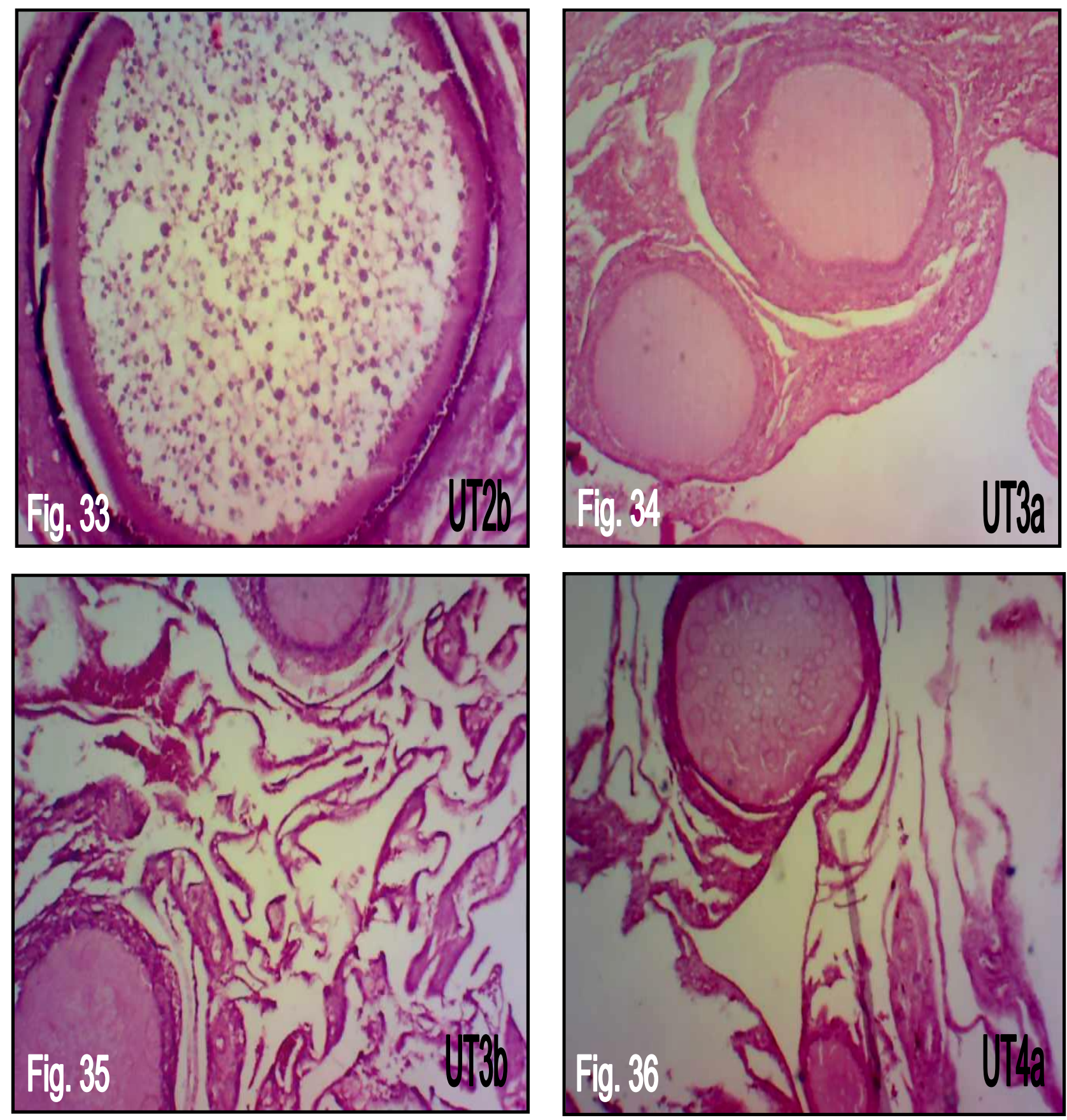

Fig. (33): ovary of Japanese quail fed diet supplied with $0.4 \%$ untreated jojoba meal protein $\left(\mathrm{UT}_{2}\right)$, showing mature ovum with reduced internal content

Fig. (34): ovary of Japanese quail fed diet supplied with $0.6 \%$ untreated jojoba meal protein $\left(\mathrm{UT}_{3}\right)$, showing normal growing follicles.

Fig. (35): ovary of Japanese quail fed diet with $0.6 \%$ untreated jojoba meal protein (UT3), showing normal growing follicles with reduced stroma

Fig. (36): ovary of Japanese quail fed diet supplied with $0.8 \%$ untreated jojoba meal protein $\left(\mathrm{UT}_{4}\right)$, showing somewhat normal growing follicle. 

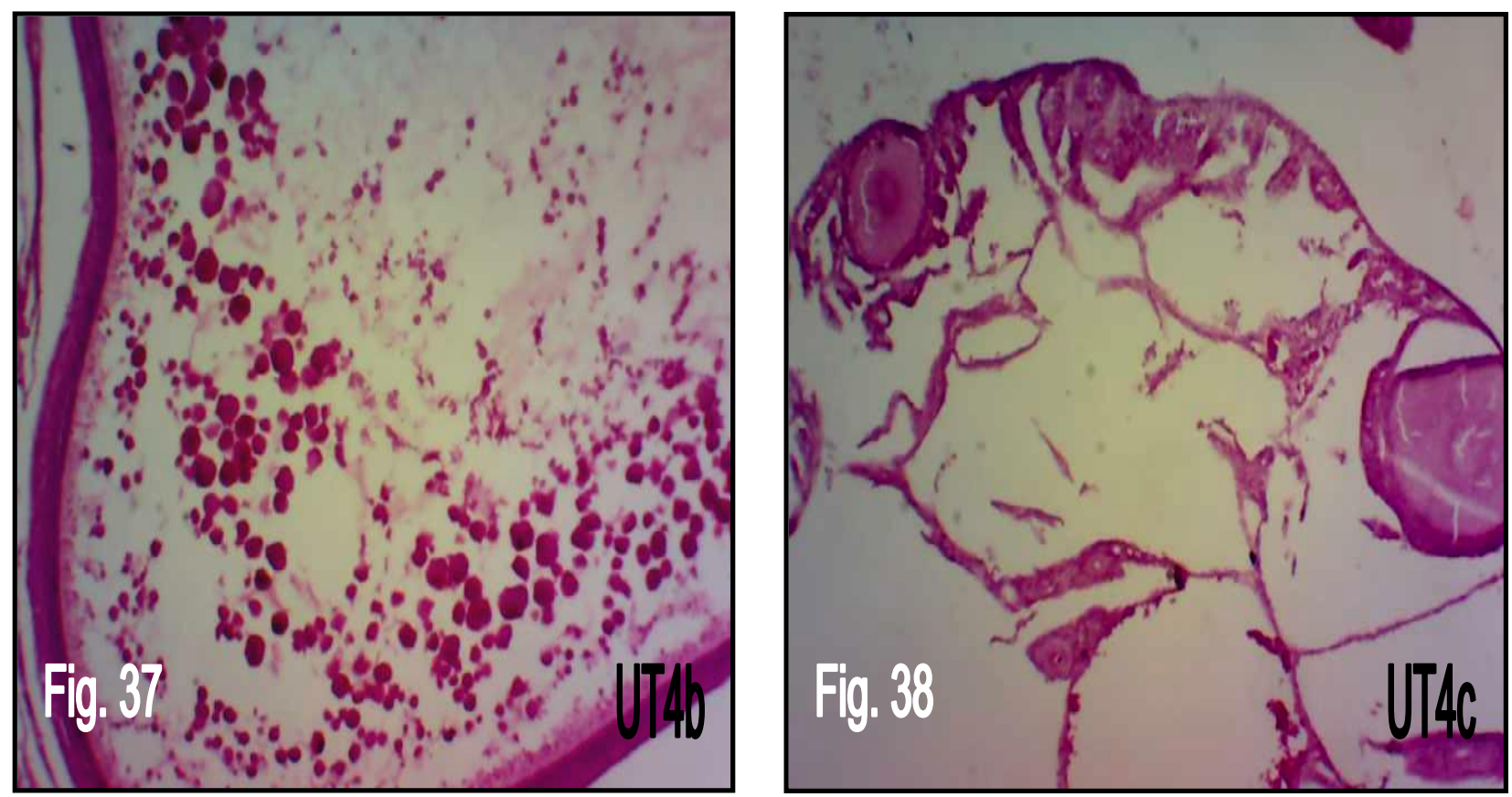

Fig. (37): ovary of Japanese quail fed diet supplied with $0.8 \%$ untreated jojoba meal protein (UT4), showing malformed mature follicles with irregular membranes and highly reduced internal content.

Fig. (38): ovary of Japanese quail fed diet supplied with $0.8 \%$ untreated jojoba meal protein (UT4), showing highly reduced stroma in the cortex and medulla of the ovary.

\section{References:}

Abbott TP, Nakamura L K Nelsen T C, Gasdrof $H$ J, Bennett $G$ A and Kleiman $R$ (1990): Microorganisms for degrading simmondsin and related cyanogenic toxins in jojoba. Applied Microbiology B i o t e c h n o log y, 34: $270-273$. Boozer C N and Herron A J (2006): Simmondsin for weight loss in rats. Int. J. Obesity, 1:6-16.

Carleton H M (1980): Carleton's Histological Technique, $5^{\text {th }}$ edition Drury, R.A.B. and Wallington, E.A.London.

Cokelaere M, Buyse J, Decuypere E, Ku"hn E andVan Boven $M$ (1993): Influence of jojoba meal supplementation on growth and organ function in rats. J. Agric. Food Chem., 41: 1444 - 1448.

EL-Anany A M (2007): Nutritional, biochemical and histopathological studies on jojoba protein isolate. Brazilian J. Food Technol., 10 (3): 198-204.

Farag S A (2007): Evaluation of jojoba meal as a foodstuff in broiler's diet. Ph.D. Thesis, faculty of Agriculture, Tanta University.

Forster K E and Wright N G (2009) : Constraints to Arizona agriculture and possible alternatives. Office of Arid land Studies, University of Tuscon, Arizona, USA.

Nofal M E, Abou-Khashaba $\mathrm{H} A$ and Ibrahem M A (2004): Productive and reproductive performance studies on layers exposed to lead and the role of natural clay in reducing adverse effects of lead poisoning. J. Agric. Sci. Mansoura Univ., 29(3): 11491167. NRC( National Research Council) (1994):
Nutrient Requirements of Poultry. $9^{\text {th }}$ revised Ed. National Academy press, Washington, DC., USA. Sobhy H M, Mohamed E A, Mansour M k and Shehab G G (2003): Influence of jojoba meal supplementation on body gain, function of organs. Kafer El-Sheikh Vet. Med. J., 1 (1): 961-982.

Steven J, Phillips P, Wentworth C (2000): A Natural History of the Sonoran Desert. University of California Press. pp. 256-257

Swingle R S, Garcia M R, Delfino F J and Prouty F L (1985): An evaluation of lactobacillus acidophilus treated jojoba meal in beaf cattle diets. J. Anim. Sci., 60: 832 - 838 .

Vorbiscar A J and Banigan TF (1978): Composition of jojoba seeds and foliage. J. Agric. Food Chem., 26(6): 1456 - 1459.

Verbisca A J , Banigan T F, Weber CW, Reid $B$ L, Trei J E, Nelson E A, Raffauf $R$ F and Kosersky D (1980): Detoxification of jojoba meal. J. Agric. Food Chem., 28: 571-578.

Wisniak J (1987): Jojoba meal. In: The Chemistry and Technology of Jojoba Oil. Wisnick, J. (Ed.).The American Oil Chemist. Society, Champaign, IL.

Wiseman M O and Price R L (1987): Characterisation of protein concentrates of jojoba (Simmondsia hinensis) meal. Cereal Chem., 64(2): 91-93.

http://www.jatrophabiodiesel.org/Jojoba/jojo ba-uses.php 


\section{التغيرات المرضية فى أنسجة بعض أعضاء السمان الياباني المعامل بمستويات

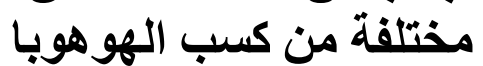

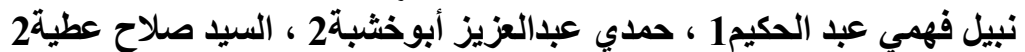

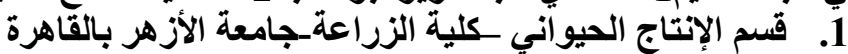
2. قسم تغذية الدواجن_معهل بحوث الإنتاج الحيواني_مركز البحوث الززراعية_الجيزة_ مصر .3

تم إجراء تجربتين لدراسة تأثير استخدام الهو هوبا المعامل و الغير معامل في الغذاء علي التغيرات المرضية لأنسجة بعض أعضاء السمان الياباني النامي من عمر أسبو ع و لمدة خمسة أسابيع.

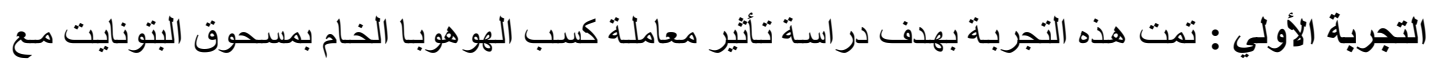

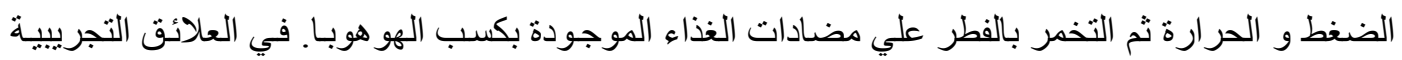

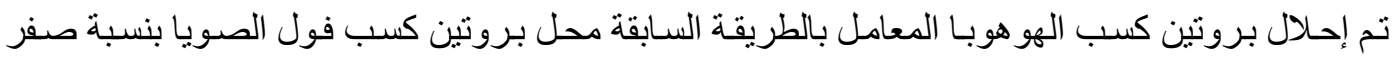

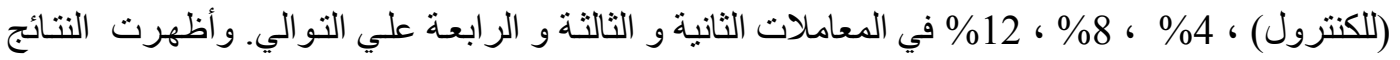

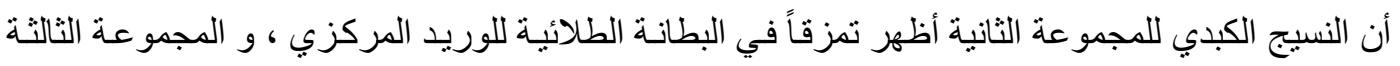

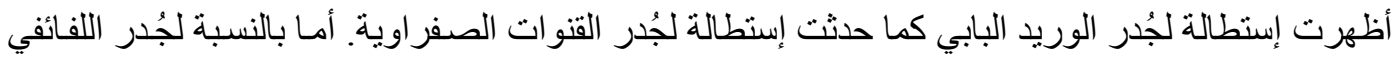

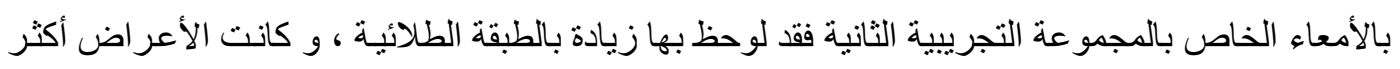

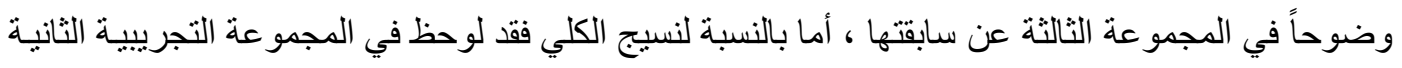
تزاحم الفراغات بين الأنابيب ، و المجموعة الثالثة ظهرت بها الأنابيب الملتفة والكبيبات في شكل طبيعي و

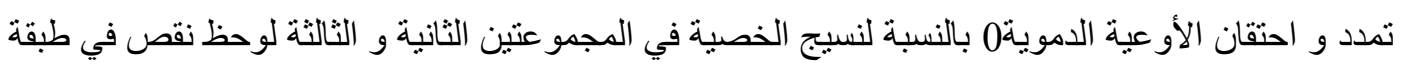

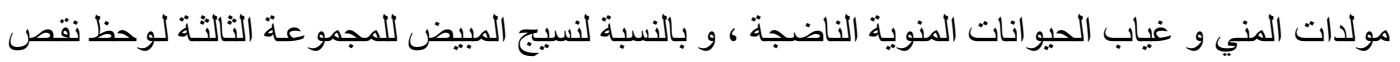

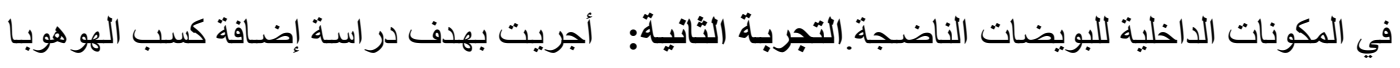

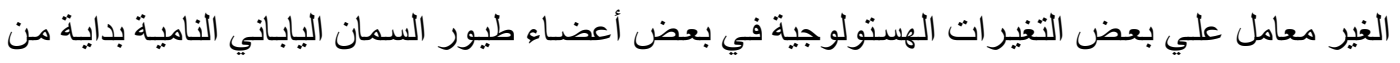

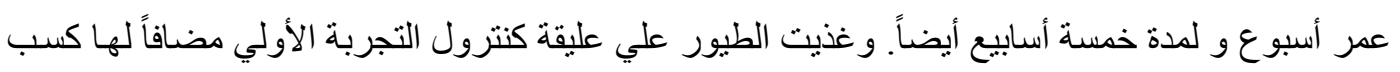

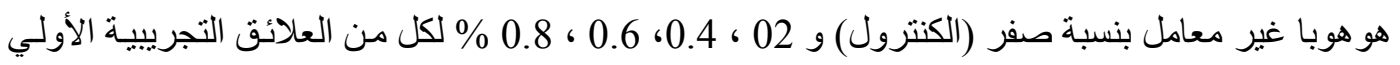

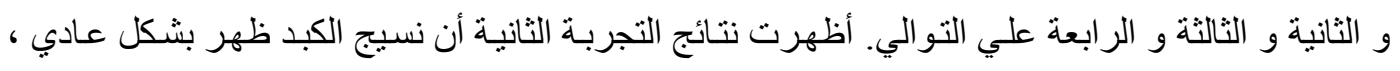

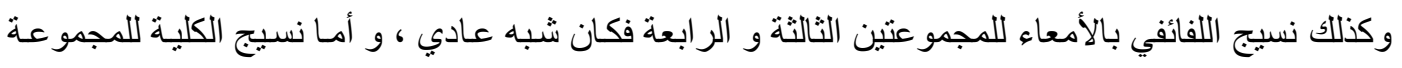

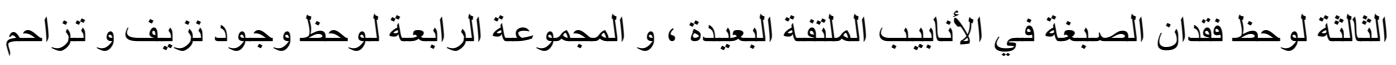

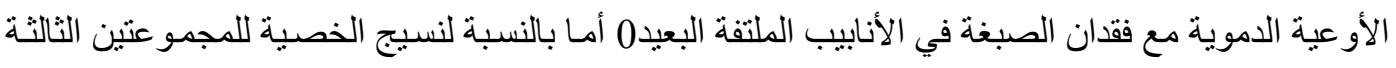

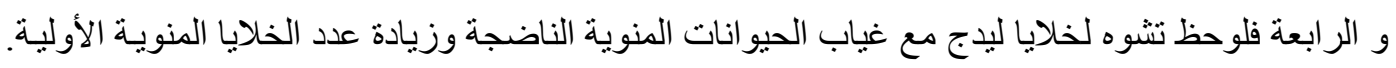

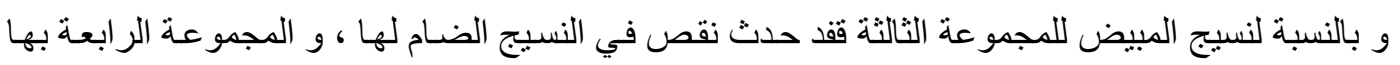

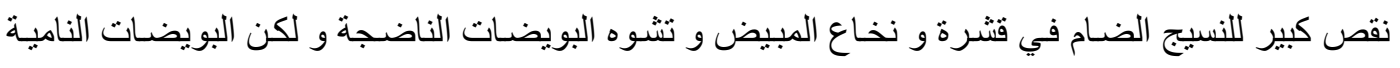

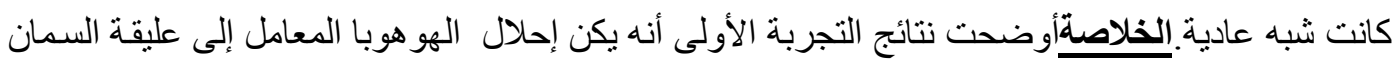

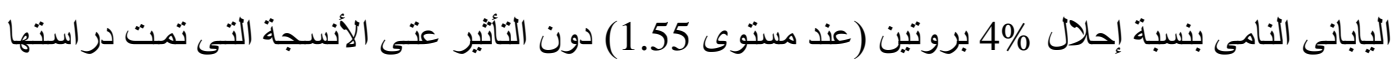

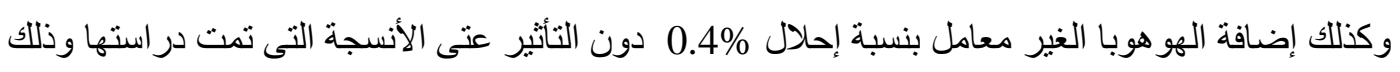
فى العلائق التجريبية الأولنو الثانية والثالثة 0 